\title{
Parasitic castration in slipper limpets infested by the symbiotic crab Calyptraeotheres garthi
}

\author{
Emiliano H. Ocampo · Jesús D. Nuñez • \\ Maximiliano Cledón · J. Antonio Baeza
}

Received: 26 May 2014 / Accepted: 29 June 2014 / Published online: 18 July 2014

(C) Springer-Verlag Berlin Heidelberg 2014

\begin{abstract}
Two ill-explored hypotheses might explain host castration by parasitic pea crabs. The 'energy drain' hypothesis states that castration is caused by host-derived nutrient consumption of parasites that ultimately diminishes host-energy intake. The 'steric interference' hypothesis states that castration occurs when parasites physically inhibit host reproduction. This study evaluated whether Calyptraeotheres garthi, a pea crab from the southwestern Atlantic, is a parasitic castrator and explored whether the two hypotheses above explain castration in the limpet Crepidula cachimilla. None of three studied limpet species brooded embryos during the reproductive season when infested by mature female pea crabs. Also, limpets of $C$. cachimilla infested by $C$. garthi did not reproduce during
\end{abstract}

Communicated by M. G. Chapman.

E. H. Ocampo $(\bowtie) \cdot$ J. D. Nuñez

Laboratorio de Invertebrados, IIMYC - Instituto de

Investigaciones Marinas y Costeras, CONICET-UNMDP,

Funes 3350, Mar del Plata 7600, Buenos Aires, Argentina

e-mail: eocampo@mdp.edu.ar

M. Cledón

EGEM-Laboratorio de Ecología y Genética de Especies Marinas, IIMYC, CONICET-UNMDP, Funes 3350, Mar del Plata 7600,

Buenos Aires, Argentina

J. A. Baeza

Department of Biological Sciences, Clemson University,

Clemson, SC 29632, USA

\section{J. A. Baeza}

Smithsonian Marine Station at Fort Pierce, Fort Pierce, FL 34949, USA

J. A. Baeza

Departamento de Biología Marina, Facultad de Ciencias del Mar,

Universidad Católica del Norte, Coquimbo, Chile a 90-day experimental period while crab-free limpets did spawn embryos during this period. Limpets resumed reproduction soon after pea crabs were experimentally removed from their brooding chamber. Thus, $C$. garthi does castrate limpets, and castration is reversible. Pea crabs 'steal' food from limpets, and infested limpets did not modify their feeding behavior to counteract nutrient loss. Thus, infested limpets are expected to ingest less food which provides partial support for the 'energy drain' hypothesis. However, the limpet's body condition increased or was not affected by pea crabs during the breeding season which argues against the same hypothesis. Furthermore, that limpets promptly recovered reproductive activity once pea crabs were experimentally removed, that castration was not induced by the smallest pea crabs in the population (that fill only partially the brooding chamber), and that parasitized limpets did exhibit fully mature ovaries, support the 'steric interference' hypothesis explaining parasitic castration.

\section{Introduction}

Parasitic associations are pervasive in both aquatic and terrestrial ecosystems and involve many levels of biological organization (Margulis and Fester 1991). Among parasites, species of 'parasitic castrators' are known to severely diminish or completely halt host reproduction (Hurd 1993; Lafferty and Kuris 2009). Castrators, in particular 'macro-parasitic castrators', also exhibit various peculiarities that distinguish them from other types of parasites. For instance, parasitic castrators establish long-term associations with their host individuals (Kuris 1974), can attain large body sizes relative to those of their host species (Kuris and Lafferty 2000) and exhibit a solitary lifestyle in/ on hosts (Lafferty and Kuris 2009). Commonly, a single 
parasitic castrator prevents host reproduction, and thus, virulence (castration) does not depend upon parasitic intensity as occurs with 'regular' parasites (Kuris 1974; Lafferty and Kuris 2009). In the absence of reproductive activity, castrated hosts function merely as an 'extended phenotype' of the parasite (Sorensen and Minchella 2001). However, in some cases, infected hosts do exhibit some reproductive activity during the early stages of an infection (Sorensen and Minchella 2001) and some hosts might even recover reproductive activity if they outlive their castrators (Kuris et al. 1980). In addition to their impact on host reproduction, parasitic castrators have been reported to either increase or decrease the growth rate and/or body condition of host individuals (Van Wyk 1982; Hall et al. 2007).

In the marine environment, parasitic castrators include, among others, rhizocephalan barnacles (Høeg 1995), bopyrid and entoniscid isopods (Williams and Boyko 2012) and larval digenean trematodes (Sorensen and Minchella 2001). Parasitic castrators are increasingly studied in marine systems, and our understanding of their life history, ecology and effects upon both host individuals and populations has improved considerably during the last decades (e.g., Blower and Roughgarden 1987; Hurd 1993; Loker and Adema 1995; Ebert et al. 2004; Miura et al. 2006). Yet, various aspects of this remarkable type of parasitism, including the mechanism(s) used by parasitic castrators to halt host reproduction, are incompletely understood. Descriptive and experimental approaches in ill-studied castrator taxa are needed for a more complete understanding of this remarkable parasitic strategy.

Within the species-rich and ecologically diverse-order Decapoda, symbiotic relationships involving crabs are common. Among decapods, the family Pinnotheridae (=pea crabs) is mostly comprised of species that associate with a wide diversity of hosts, including gastropods, bivalves, ascidians, holothurians, echinoids and sea urchins (Schmitt et al. 1973). Pea crabs can and do exert deleterious effects upon host individuals (e.g., Orton 1920; Stauber 1945; Bierbaum and Shumway 1988), and therefore, pea crabs are increasingly considered parasites rather than commensals (e.g., Bierbaum and Shumway 1988; De Bruyn et al. 2009). Some pea crab species, in particular those infecting bivalves and gastropods, have been reported to entirely halt or decrease host reproduction (Berner 1952; Yoo and Kajihara 1985; O'Beirn and Walker 1999; Chaparro et al. 2001). Thus, these pea crabs that dwell in the mantle cavity of mollusk can be considered parasitic castrators (Lafferty and Kuris 2009).

Two hypotheses that have rarely been explored might explain host castration by pea crabs. First, the 'energy drain' hypothesis proposes that parasitic castrators, such as pea crabs, cause host reproductive cessation by depleting energy reserves from host individuals due to food deprivation and/or damage of tissues imposed by these parasites (Walker 1977; Van Wyk 1982; Hurd 1993; Polak 1996). This first hypothesis appears to explain castration in insects infested by parasitic mites (Polak 1996) and crabs harboring parasitic isopods (Van Wyk 1982) and might also explain the absence of reproductive activity in bivalve hosts infested by pea crabs. For instance, pea crabs inhabiting the mantle cavity of bivalves feed on food-rich mucous cords produced by hosts when filtering suspended particles from the water column (Bierbaum and Shumway 1988). As occur in other castrated hosts (see Van Wyk 1982; Polak 1996), infested bivalves might drastically reduce (Yoo and Kajihara 1985) or entirely suppress (Berner 1952) their reproductive activity due to the nutritional stress imposed by pea crabs. Considering that this type of parasitic castration is a 'by-product' of host-energy depletion caused by the parasites, other energy-demanding processes are also expected to be affected during infestation (Anderson 1977; Sousa 1983). Indeed, a decrease in the overall condition and/or growth rate is commonly reported in castrations caused by parasite-mediated energy draining (Anderson 1977; Van Wyk 1982; Sousa 1983).

The second hypothesis that might explain host castration by pea crabs assumes that castration is simply a consequence of the presence of the castrator that physically interferes with the reproductive processes of the host individuals. For instance, host species that brood offspring in body cavities will be 'forced' to discontinue spawning if parasitic castrators occupy the same cavity harboring the host's offspring. At present, the only study supporting this hypothesis, here named the 'steric interference' hypothesis, is that conducted in Calyptraeotheres sp. from the southeastern Pacific. This pea crab colonizes the incubatory egg chamber of the slipper limpet Crepipatella fecunda (Chaparro et al. 2001). The space available within this 'incubatory chamber' is the main factor determining whether spawning occurs or not (Chaparro et al. 2001) and either the presence of a pea crab or a false pea crab (i.e., a crabsized piece of parafilm) results in host individuals halting reproduction (Chaparro et al. 2001). The 'steric interference' hypothesis predicts that reproductive activity should recover quickly after death (or experimental removal) of pea crabs (Chaparro et al. 2001).

In this study, we are interested in understanding the strategies used by pea crabs to castrate host individuals. For this purpose, we used Calyptraeotheres garthi as a model system, a pea crab that inhabits the mantle cavity of almost all naturally occurring slipper limpets from the southwestern Atlantic (Ocampo et al. 2012a, b). The space in the mantle cavity inhabited by this pea crab is also used by the same limpets to incubate embryos (this space is hereafter referred as an 'incubatory' or 'brooding' chamber). C. garthi increases the metabolic rate of one of its 
host species, i.e., the slipper limpet Crepidula cachimilla. The above clearly suggests a parasitic relationship between pea crabs and limpets (Ocampo et al. 2014). Furthermore, preliminary observations suggest that limpets harboring $C$. garthi do not brood embryos (Ocampo et al. 2012a). However, whether or not the 'steric interference' hypothesis, as demonstrated in the closely related crab Calyptraeotheres sp. (Chaparro et al. 2001), also explains castration in C. garthi's limpet host needs to be explored. Lastly, slipper limpets are suspension feeders (Chaparro et al. 2002), and preliminary observations suggest that Calyptraeotheres directly obtain food (i.e., previously filtrated and concentrated particles) from host individuals (Chaparro et al. 2001). Whether or not a putative nutritional dependence of pea crabs from limpets results in diminished food acquisition by host individuals, and consequently, halts host reproduction remains to be addressed.

Herein, first, we evaluated whether $C$. garthi affects spawning and brooding of egg masses in three different host species of slipper limpets. The above will help us to determine whether or not $C$. garthi is indeed a parasitic castrator. Second, we analyzed whether castration in limpets results solely from the physical presence of pea crabs (Chaparro et al. 2001) or whether a putative nutritional dependence of crabs from limpets also impacts host reproduction, as reported before in other host species inhabited by pea crabs (Berner 1952; Yoo and Kajihara 1985). To accomplish these goals, (1) we analyzed the relationship between the occurrence of pea crabs and the presence/absence of egg capsules in natural populations of three different slipper limpets, $C$. cachimilla, $C$. argentina and Bostrycapulus odites; (2) we manipulated the presence/absence of symbiotic crabs in host individuals $(C$. cachimilla) to determine whether the effect of crabs on host reproduction was reversible; (3) we analyzed the feeding mechanism of $C$. garthi and conducted laboratory experiments to determine whether or not the crab feeding activity impacts the host's feeding efficiency; and (4) we explored the effect of $C$. garthi on the body condition of the limpet C. cachimilla.

\section{Materials and methods}

Collection of slipper limpets and pea crabs

Crepidula cachimilla, C. argentina and B. odites were collected during a 5-year period (2007-2011) from different localities in the southwestern Atlantic (see sampling details in Table 1). C. cachimilla and $C$. argentina most often attach to the external shell surface of the mussel Mytilus edulis, while $B$. odites is mostly found attached to rocks of various sizes. 
After collection, limpets were immediately detached from their substrata and the mantle cavity of each limpet was carefully inspected. The presence/absence of egg masses and pea crabs was registered in all collected limpets. Then, limpets were fixed (formaldehyde $4 \%$ ) and individually stored. The shell length (SL) of each limpet was measured with digital calipers to the nearest $0.1 \mathrm{~mm}$ and sexed on the basis of the presence or absence of a penis (Cledón et al. 2004). The carapace width (CW) of each crab was measured under the stereomicroscope equipped with a calibrated ocular micrometer (precision $=0.01 \mathrm{~mm}$ ). Crabs were sexed based on the presence or absence of male gonopods (McLaughlin 1980). Lastly, crabs were classified either as pre-hard stage, hard stage or stages II-V.

In pea crabs from the subfamily Pinnotheridae, including $C$. garthi, the life cycle is complex and involves considerable changes in body shape after settlement (Møller Christensen and McDermott 1958; Pearce 1966; Ocampo and Baeza unpubl data). First post-larval 'megalopa' stage molts into small and soft-shelled first crab instars, called 'pre-hard' stages, which infect host individuals. Pre-hard stages later molt into second small but hard-shelled crab instars, called 'hard-stages'. Crabs attaining hard-shelled stages apparently leave host individuals in search of mating partners (Pearce 1966). After mating takes place, female hard-stage crabs colonize the same or another host individual and molt four more times into soft "posthard' instars (stages II-V). Females appear to store sperm in their seminal receptacles during the post-hard stages, and egg fertilization takes place later in the last post-hard instar (stage-V) (Becker et al. 2011). Females become sexually mature at stage- $\mathrm{V}$ and start spawning and brooding eggs beneath the abdomen (Becker et al. 2011). Throughout stages II-V, female crabs do not appear to abandon their host individuals (Møller Christensen and McDermott 1958; Pearce 1966). Males, instead, putatively leave their hosts and roam in search of copulations (Ocampo et al. 2012a). The formal description of the different post-settlement stages in C. garthi is in progress (Ocampo and Baeza unpubl data).

For experiments involving living crabs and limpets, additional specimens of $C$. cachimilla collected during September 2010 from San Matias Gulf were quickly placed in thermal containers with aerated seawater and then transported alive to the laboratory (Laboratory of Marine Ecology and Genetics, National University of Mar del Plata, Argentina). There, limpets were acclimatized and maintained in 300-L containers with flowing seawater $\left(6-10 \mathrm{~L} \mathrm{~min}^{-1}\right)$ at $20-22{ }^{\circ} \mathrm{C}$ and 34 PSU for at least 2 weeks before the start of the different experiments. During acclimatization, limpets were fed daily with ad libitum aliquots of unicellular algae Nannochloropsis oculata and Tetraselmis suecica.
Presence of Calyptraeotheres garthi and host spawning: field data

We evaluated whether $C$. garthi affects spawning and brooding of egg masses in three different host species; $C$. cachimilla, $C$. argentina and $B$. odites. In pea crabs, including $C$. garthi, females stage II-V establish long-term associations and attain large sizes while males and females in pre-hard and hard stages spend short time periods with a specific host individual and have comparatively small body sizes (Pearce 1966; Ocampo et al. 2012a). To determine the effect of $C$. garthi on spawning of limpets, we constructed two different two-way contingency tables. In the first contingency table, we used the presence/absence of egg masses and presence/absence of crabs (either male or female crabs) in pre-hard and hard stages as categorical variables. In the second contingency table, we used the presence/absence of egg masses and the presence/absence of female (stages II-V) crabs as categorical variables. In each analysis, we considered only limpets collected during the breeding season (see Table 1) and only sexually mature limpets, i.e., larger than the smallest limpet observed brooding eggs (>17.5, 15.0 and $11.5 \mathrm{~mm} \mathrm{SL}$ in C. cachimilla, C. argentina and $B$. odites, respectively, see Cledón and Penchaszadeh 2001; Cledón et al. 2004). The observed frequencies of occurrence were compared with expected frequencies calculated under the null hypothesis of independence between the presence of egg masses and the presence of crabs. Significant differences between the observed and expected frequencies were examined using a chi-square test of independence (Sokal and Rohlf 1981). If the chi-square test detected differences, then we concluded that crabs do affect the spawning and/or brooding of limpets harboring them.

\section{Effect of Calyptraeotheres garthi on host spawning:}

laboratory experiment

Field data suggested an effect of female (stage II-V) crabs on the spawning of the studied limpets (see 'Results' section). We further investigated whether or not the effect of mature (stage- $\mathrm{V}$ ) female crabs on the ability of limpets to spawn and successfully brood embryos was irreversible. For this purpose, living specimens of $C$. cachimilla were detached from their substrate and then each limpet was individually reattached to a new substrate consisting of a small piece of transparent glass that permitted the observation of the crab and the egg masses in the mantle cavity (see Ocampo et al. 2012a). Next, we selected 15 limpets $(X \pm \mathrm{SD}=33.5 \pm 7.4 \mathrm{~mm} \mathrm{SL})$ without crabs and 19 limpets $(X \pm \mathrm{SD}=34.9 \pm 9.1 \mathrm{~mm} \mathrm{SL})$ harboring mature (stage- $\mathrm{V}$ ) female crabs. Each of the limpets above was daily inspected for egg capsules during a total of 90 days (from January 22, 2011 to April 22, 2011). 
A third group of limpets consisted of five specimens $(X \pm \mathrm{SD}=35.2 \pm 10.1 \mathrm{~mm} \mathrm{SL})$ that were detached from their substrate (glass pieces) and from which mature female crabs occupying the limpet's mantle cavity were gently removed with forceps. These limpets stripped of crabs were reattached to the same glass pieces, acclimatized during 1 week and then inspected daily for egg capsules during the next 20 days (April 2-April 22, 2011). All limpets were cultured in a 300-L container and were fed daily and ad libitum with microalgae $N$. oculata and T. suecica. For each limpet, we recorded the day of oviposition of egg capsules and hatching of larvae. If limpets stripped of crabs deposited eggs, then we concluded that the effect of crabs on spawning is reversible. No differences in body size were detected among the three groups of experimental limpets [ANOVA, $F_{(2,36)}=0.286, P=0.753$ ].

Feeding behavior of the pea crab Calyptraeotheres garthi

Adult limpets in the family Calyptraeidae feed on suspended particles, including phytoplankton (Chaparro et al. 2002). Particles are captured by the gill, concentrated and intermittently transferred in the form of food-rich mucus cords along a food canal to the mouth where these mucus cords are either ingested or discarded as pseudofeces by limpets (Chaparro et al. 2002). We aimed at revealing any klepto-parasitic activity of $C$. garthi by direct observation of crabs dwelling within limpets in the laboratory. For this purpose, living specimens of $C$. cachimilla were detached from their substrate and crabs found inside them were gently extracted, measured and sexed as above. Next, each crab was returned to the same host individual from which it was originally extracted and each limpet was reattached to a piece of transparent glass as above. Crabs and the limpets harboring them were placed in $0.5-\mathrm{L}$ transparent plastic containers containing seawater with a concentration of $12 \times 10^{3}$ cell $\mathrm{mL}^{-1}$ of $T$. suecica. Each limpet was placed almost vertically with respect to the wall of the container to allow observations of the mantle cavity containing the crab. Each crab was continuously observed for a total of $4 \mathrm{~h}$. Observations were made from a position beneath the containers at an angle of about $45^{\circ}$ from the wall of the container. From this position, it was possible to observe inside host individuals, avoiding being (the observer) detected by the crab. Also, to minimize stress for experimental crabs, observations were conducted with dim light. We recorded the feeding behavior of a total of 9 stage- $\mathrm{V}$ females and 3 hard-stage males of $C$. garthi. We also recorded the feeding behavior of other 14 stage- $\mathrm{V}$ females during the experiments in which mucous production and pseudofeces elimination by limpets were measured (see below).

During our observations, we recorded (1) whether or not crabs consume host-derived food and/or pseudofeces; and
(2) whether crabs remain in the same position within hosts or whether crabs change their position and move while within hosts to ingest food from other structures (e.g., gill and/or the anterior section of the neck). The semi-translucent and thin carapace of crabs (males and females) permitted us to record whether or not crabs consume host-derived food as indicated by changes in the color of their stomachs.

Feeding activity of Crepidula cachimilla: the effect of pea crabs on clearance rate

We evaluated the effect of $C$. garthi on the feeding activity of $C$. cachimilla adult limpets. For this purpose, we measured the clearance rate $(\mathrm{CR})$, i.e., the rate at which phytoplankton concentration declines through time in closed containers (Marin et al. 1986), in limpets harboring or without stage- $\mathrm{V}$ female crabs. We recorded the $\mathrm{CR}$ in a total of 62 different limpets during experiments that lasted $4 \mathrm{~h}$ using an initial phytoplankton concentration of $12 \times 10^{3}$ cell $\mathrm{mL}^{-1}$ of $T$. suecica. We chose this initial concentration because (1) in C. cachimilla, pseudofeces production is low at this concentration, and (2) a pilot experiment (data not shown) demonstrated that within the $6 \times 10^{3}-30 \times 10^{3}$ cell $\mathrm{mL}^{-1}$ concentration range, the $\mathrm{CR}$ of $C$. cachimilla does not depend on the concentration of $T$. suecica. Therefore, using this initial concentration (i.e., $12 \times 10^{3}$ cell $\mathrm{mL}^{-1}$ ), we ensured that any minor variation in phytoplankton concentration among experimental containers did not affect the CR of the experimental limpets. Prior to the experiment, the shell of each limpet was gently scraped to remove any filter-feeding epibiont (e.g., polychaete worms) which might have affected our CR measures. The hunger level of each limpet was standardized by starving limpets during $24 \mathrm{~h}$ before the experiment while keeping them in aquaria (20 L) containing $1 \mu \mathrm{m}$ filtered seawater. Next, each limpet was individually placed in a 0.5 -L container (flask) partially filled, i.e., containing $0.4 \mathrm{~L}$ of filtered seawater. After a period of acclimatization of $\geq 20 \mathrm{~min}$, we added $0.1 \mathrm{~L}$ of a dilution of T. suecica reaching the required concentration and completing the $0.5-\mathrm{L}$ final volume. We conducted 5-10 replicates daily using different limpet individuals. Also, we used two control flasks daily each containing the same initial phytoplankton concentration and volume but no limpets. These control flasks permitted detecting any change in phytoplankton concentration which may be attributed to cell mortality or cell division occurring during the experiment (see Pechenik and Eyster 1989). Gentle bubbling helped to maintain the homogeneity of the phytoplankton suspension in all control and experimental containers.

One microliter water samples were taken from all containers immediately (time 0 ) and 1, 2, 3 and $4 \mathrm{~h}$ after the start of the experiment. Water samples were immediately preserved with $0.05 \mathrm{~mL}$ of Lugol's iodine, and 
phytoplankton cell counts were conducted under the microscope using a glass hemocytometer. Each cell concentration estimate was based on at least two sub-samples from each container. Next, cell concentrations of experimental containers were corrected according to changes (if any) in control containers. The CR (liters $\times$ limpet $^{-1} \times$ hour $^{-1}$ ) was calculated from the exponential rate of decrease of T. suecica concentration in a closed system as function of time (Coughlan 1969). To avoid underestimations of the $\mathrm{CR}$, this rate was calculated using cell concentrations at times 0,1 and 2 .

At the end of the experiment, each limpet was detached from its substrate (mussel valve) and the presence/absence of pea crabs was determined. The average $( \pm \mathrm{SD})$ body size of specimens of $C$. cachimilla harboring and not harboring stage- $\mathrm{V}$ female crabs was $35.74 \pm 3.08 \mathrm{~mm}$ and $34.39 \pm 3.59 \mathrm{~mm}$ SL, respectively. No significant differences in SL of the limpets with and without crabs were detected $\left(t\right.$ test, $\left.t_{57}=1.638, P=0.107\right)$.

We compared the CR between limpets without crab and those harboring stage-V female crabs using a Student's $t$ test (Sokal and Rohlf 1981). Prior to the $t$ test, the dataset was tested for normality (Shapiro-Wilks test) and for homogeneity of variances (Cochran's test) and data points were transformed (if necessary) to meet statistical assumptions (Zar 1999). If the Student's $t$ test detected a significant difference in CR between limpets harboring or without symbiotic crabs, then we concluded that mature female crabs of C. garthi affect the CR of limpets.

Feeding activity of Crepidula cachimilla: the effect of pea crabs on mucous cord formation and pseudofeces elimination

To evaluate the effect of $C$. garthi on the feeding activity of C. cachimilla, we also measured the production of mucous cords (PM) in the food canal and elimination of pseudofeces (EP) in limpets harboring or without mature (stage-V) female crabs. PM is defined herein as the number of times per hour that limpets loaded a phytoplankton-rich mucous cord into the food canal, transferred this cord to the mouth and finally ingested this phytoplankton-rich mucous cord. In turn, EP is defined as the number of times per hour that a phytoplankton-rich mucous cord was loaded into the food canal but was then rejected by the limpet and discarded as pseudofeces. Other sources of pseudofeces (e.g., balls of pseudofeces liberated from the food pouch), which are sporadically produced by limpets (see Shumway et al. 2014), were not quantified herein.

Limpets were detached from their original substrates and then reattached to glass as above. The hunger level of limpets was also standardized as above. Next, each limpet was placed individually in 0.5 -L transparent plastic containers containing water with $12 \times 10^{3}$ cell $\mathrm{mL}^{-1}$ of $T$. suecica. After a period of acclimatization of $\geq 20 \mathrm{~min}$, one observer (E.O.) determined PM and EP continuously during $4 \mathrm{~h}$. Since PM and EP were registered by naked eye, both length and diameter of the mucous cord were not quantified. Homogeneous mixing of phytoplankton cells was maintained with gentle bubbling. PM and EP were recorded in a total of 31 limpets of $C$. cachimilla, 17 without crabs and 14 hosting stage- $\mathrm{V}$ female crabs. The average $( \pm \mathrm{SD})$ body size of these limpets harboring and not harboring stage- $\mathrm{V}$ female crabs was $28.9 \pm 3.3 \mathrm{~mm}$ and $27.7 \pm 5.1 \mathrm{~mm} \mathrm{SL}$, respectively. No significant differences in SL of limpets harboring and not harboring crabs were detected $(t$ test, $\left.t_{27}=0.942, P=0.354\right)$.

We compared the PM and EP between limpets without crab and those harboring mature female crabs using a Student's $t$ test (Sokal and Rohlf 1981). For the EP dataset, Cochran's test revealed heterogeneity of the variances, which was not possible to eliminate after data transformation (i.e., logarithmic, arcsine). Thus, the nonparametric Mann-Whitney $U$ test was used to detect possible differences in EP (Zar 1999). If the Student's $t$ test and/or MannWhitney $U$ test detected a significant difference, then we concluded that mature female crabs of $C$. garthi affect the PM and/or EP of limpets.

The effect of Calyptraeotheres garthi on the body condition of Crepidula cachimilla

We tested whether or not the presence of female crabs (stages II-V) affects the body condition of their hosts using C. cachimilla limpets collected during three different seasons; spring (December 2007), summer (February 2008) and winter (August 2010). In the laboratory, the soft body of each limpet was carefully separated from its shell with forceps, dried for $48 \mathrm{~h}$ at $60{ }^{\circ} \mathrm{C}$ and weighed with an analytical balance (precision $=0.01 \mathrm{mg}$ ). Taking into account that slipper limpets exhibit high shell shape variability, conventional condition indices (CIs) based on shell volume do not work properly (see Thain 1984). Thus, we used the dried weight of the soft body parts divided by the total weight (soft body parts + shell) as a CI in the studied species (Ocampo et al. 2014). We compared the CI between limpets without crab and those harboring female crabs (stages II-V) using three different Student's $t$ test (Sokal and Rohlf 1981), one per sampling season. Prior to the $t$ test, the dataset was tested for normality and homogeneity of variances, and data points were transformed (if necessary) to meet statistical assumptions as above. Differences in the condition between limpets of $C$. cachimilla harboring and not harboring crabs were also investigated with three different analyses of covariance (ANCOVA). In the ANCOVAs, we used the presence/absence of 
Table 2 Mean carapace width ( $\mathrm{mm}, X \pm \mathrm{SD}$ ) and number of individuals (in brackets) of the pea crab $C$. garthi collected from within three limpet species

\begin{tabular}{llll}
\hline & $\begin{array}{l}\text { Male and female } \\
\text { pre-hard }\end{array}$ & $\begin{array}{l}\text { Male and } \\
\text { female hard }\end{array}$ & $\begin{array}{l}\text { Female stage } \\
\text { II-V }\end{array}$ \\
\hline C. cachimilla & $1.2 \pm 0.4(11)$ & $2.1 \pm 0.4(31)$ & $4.8 \pm 1.5(200)$ \\
C. argentina & $1.3 \pm 0.4(13)$ & $1.8 \pm 0.3(20)$ & $3.1 \pm 0.9(26)$ \\
B. odites & $1.5(1)$ & $2.1 \pm 0.5(11)$ & $4.3 \pm 1.6(44)$ \\
\hline
\end{tabular}

female crabs (stage II-V) as the main categorical factor, SL of C. cachimilla as the covariate and body weight (log transformed) as the dependent variable. We assumed homogeneity of slopes if there was not significant interaction between the main categorical factor and the covariate (Sokal and Rohlf 1981). In the case the slopes were heterogeneous, we applied the Johnson-Neyman (JN) test to identify the range of body size in which the elevation of the curves was significantly different from each other (Huitema 1980; Hunka and Leighton 1997). The JN analysis detects those values of the covariate (SL) at which there is and there is not a significant effect of the main factor on the condition of the limpet. If the Student's $t$ test and/or JN analyses detected a significant effect of the presence of a crab in the CI and/or body weight of limpets, then we concluded that female crabs (stage II-V) of C. garthi affect the condition of limpets.

\section{Results}

Presence of Calyptraeotheres garthi and host spawning: field data

A total of 354 C. cachimilla, 434 C. argentina and 1,267 B. odites were collected during a 5 -year period. The frequency of occurrence of crabs in C. cachimilla, $C$. argentina and $B$. odites was $68.4,13.6$ and $4.4 \%$, respectively. Body sizes of crabs (pre-hard, hard and stage II-V) retrieved from the different limpet species are shown in Table 2.

During the reproductive season, a total of 24 (31\%), 99 (36\%) and $317(35 \%)$ crab-free limpets of C. cachimilla, $C$. argentina and $B$. odites were found incubating eggs in their brooding chambers, respectively. By contrast, none of the limpets harboring female crabs (stage II-V) brooded egg masses during the same time period (Fig. 1). Thus, stage II-V female crabs affected the occurrence of egg masses in the three studied limpets (chi-square test of independence: $\chi_{1}^{2}=46.86, P<0.0001 ; \chi_{1}^{2}=9.11, P<0.001$; $\chi_{1}^{2}=15.41, P<0.0001$, in $C$. cachimilla, $C$. argentina and B. odites, respectively) (Fig. 1).

In $B$. odites, the co-occurrence of egg masses and hard and pre-hard stage crabs (both males and females) was also lower than expected under the null hypothesis of independence (chi-square test of independence: $\chi_{1}^{2}=4.24$, $P<0.05$ ) (Fig. 1). As observed in limpets harboring stage
Fig. 1 Frequency distribution of brooding and non-brooding limpet hosts (C. cachimilla, $C$. argentina and $B$. odites), harboring and not harboring female crabs (stages II-V) or male and female crabs (stages hard or pre-hard). Pictures correspond to averaged sized adult specimens of the different limpet species. Scale bar $0.5 \mathrm{~cm}$
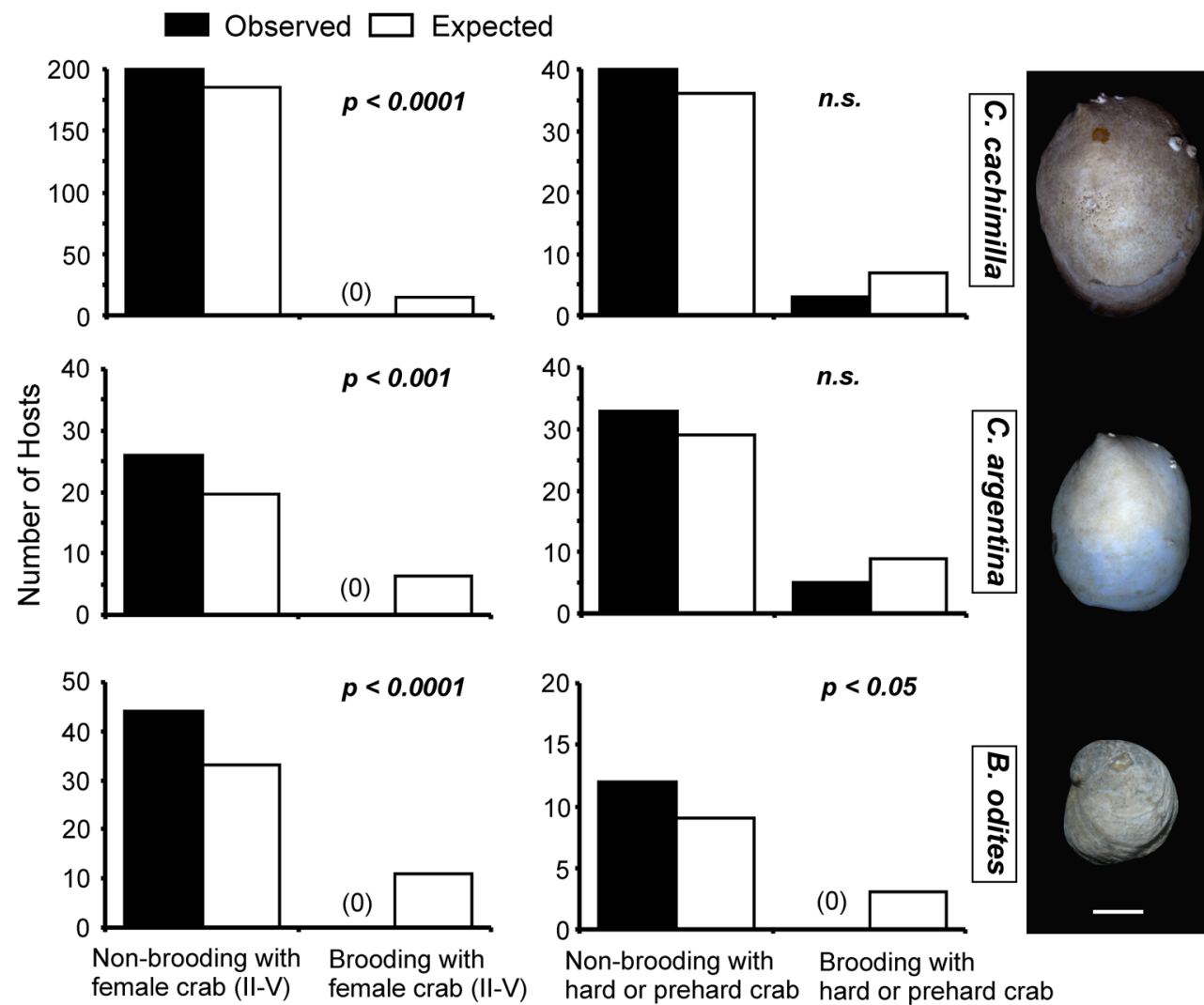

hard or prehard crab hard or prehard crab 
II-V female crabs, B. odites limpets harboring male or female crabs in hard and pre-hard stages did not brood eggs (Fig. 1). By contrast, in C. cachimilla and C. argentina, the frequency of egg masses did not vary between limpets harboring male or female crabs (hard and pre-hard stages) and crab-free limpets (chi-square test of independence: $C$. cachimilla: $\chi_{1}^{2}=3.57, P>0.05 ;$ C. argentina: $\chi_{1}^{2}=2.81$, $P>0.05)$. In these two species, a total of $3(7.5 \%)$ and 5 (15\%) limpets were observed incubating egg masses and harboring either male or female crabs (hard and pre-hard stages), respectively.

Overall, stage II-V female crabs of $C$. garthi do affect the spawning and/or brooding behavior of the three studied limpet species. In turn, male and female crabs in hard and pre-hard stages did affect spawning and/or brooding in $B$. odites but not in $C$. cachimilla and $C$. argentina.

Effect of Calyptraeotheres garthi on host spawning: laboratory experiment

Limpets of $C$. cachimilla harboring mature (stage-V) female crabs did not spawn eggs during the entire experimental period that lasted 90 days (Fig. 2). In contrast, 8 out of the 15 limpets not harboring stage-V female crabs

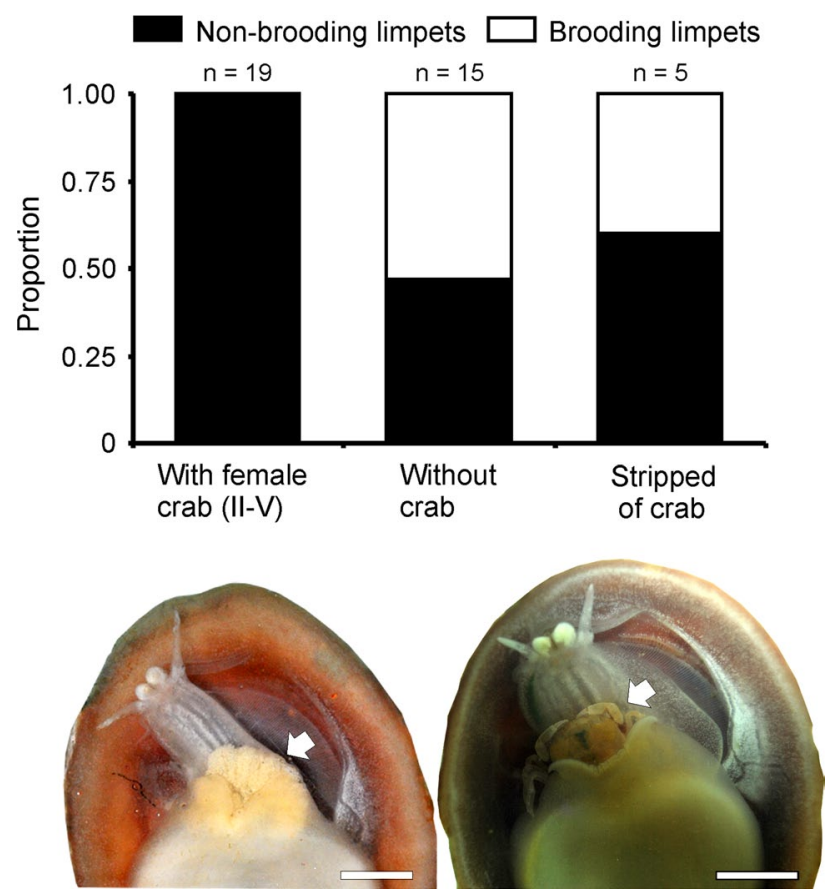

Fig. 2 Above proportion of limpets of C. cachimilla that spawned and brooded eggs during the entire experimental period, which lasted 90 days in limpets with and without female crabs (stage II-V), and 20 days in limpets stripped of female crabs. Below ventral view of limpets of $C$. cachimilla brooding eggs (on left, arrow points to egg masses) and harboring a mature female crab (on right, arrow points to the crab). Scale bars $0.5 \mathrm{~cm}$ spawned and brooded eggs (Fig. 2) during the same time period. Limpets not harboring mature female crabs spawned, on average $( \pm \mathrm{SD}), 2.6 \pm 1.4$ times during this period (incubation period $X \pm \mathrm{SD}=10.5 \pm 2.6$ days, interspawning period $X \pm \mathrm{SD}=10.8 \pm 5.8$ days). A total of 2 out of 5 limpets stripped of stage- $V$ female crabs also spawned eggs (once each) during a 20-day experimental period (Fig. 2). These two limpets spawned eggs 7 and 10 days after extraction of symbiotic crabs from their mantle cavities. Overall, stage-V female crabs do cause temporary castration in $C$. cachimilla because at least two formally infested limpets recovered the ability to spawn and incubate eggs quickly after extraction of their symbiotic crabs. Finally, after the experiment ended, we macroscopically examined the gonads in the 19 experimental limpets harboring stage- $V$ female crabs and found that 11 of them had ovaries full of mature oocytes.

Feeding behavior of the limpet Crepidula cachimilla and the pea crab Calyptraeotheres garthi

Feeding behavior of the slipper limpet $C$. cachimilla was stereotyped. Limpets fed by concentrating phytoplankton and forming mucous strings in the distal region of the gill filaments. These strings are then accumulated into a phytoplankton-rich mucous cord within the food canal in the neck. These phytoplankton-rich mucous cords were then slowly transferred from the neck canal to the mouth (Fig. 3). Each cord was either ingested (Fig. 3a-d) or rejected as pseudofeces (Fig. 3e, f). After completion of this process (Fig. 3a-f), the food canal remained clean until a new cord was loaded. Male and female crabs of $C$. garthi were observed to actively feed on phytoplanktonrich mucous cords produced by $C$. cachimilla limpets. This feeding activity was also stereotyped and involved the use of the two claws by crabs. Each crab first introduced the left claw underneath the neck of the limpet to grasp a piece of phytoplankton-rich mucous (Fig. $3 g-j$ ). Next, crabs used both claws to insert the captured piece of mucous into their mouth parts (Fig. 3k, 1). During feeding, the crab stomachs changed in coloration from 'whitish' (when empty) to 'greenish' after a piece of mucous cord was ingested (Fig. 4). In all 3 males (100\%) and in 18 out of 23 females (78 \%), we observed the same behavioral sequence and noticed shifts in stomach coloration from whitish to greenish while the crabs were feeding. Crabs started to feed during the first hour of the experiment, and they continue feeding during the $4 \mathrm{~h}$ that lasted our observations. In the remaining 5 experimental female crabs, neither claw movements nor changes in the coloration of the stomach were detected. Crabs were never observed to feed on pseudofeces. During feeding, crabs invariably position themselves between the propodium and the ventral side of 
a

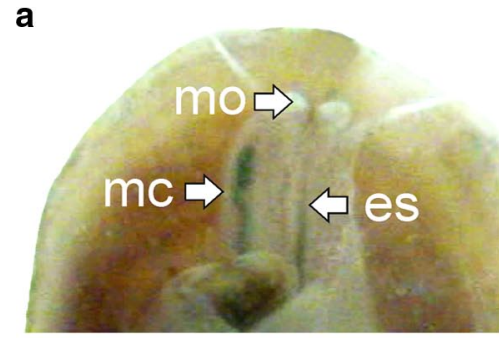

d

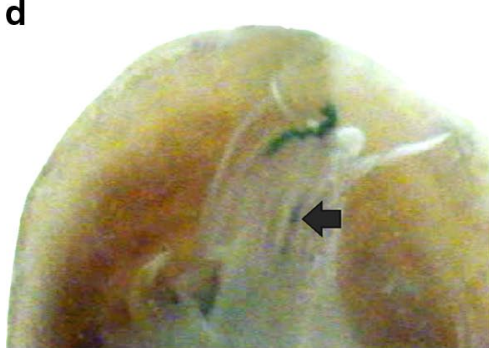

g

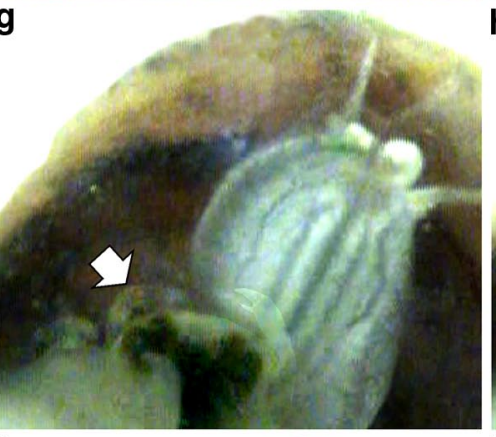

j

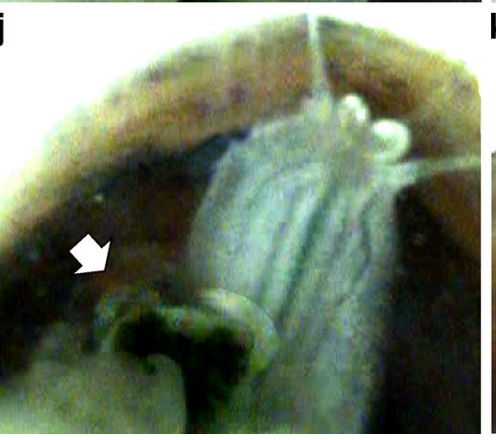

b

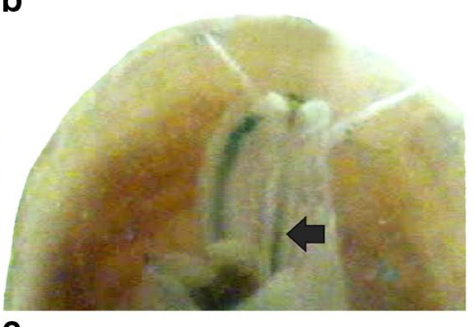

e

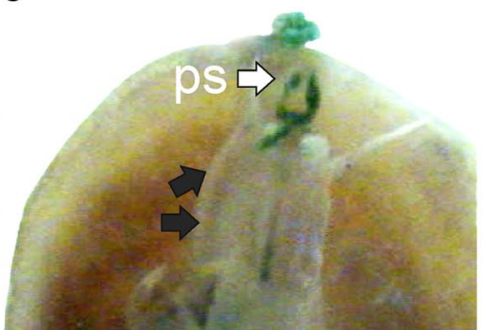

h
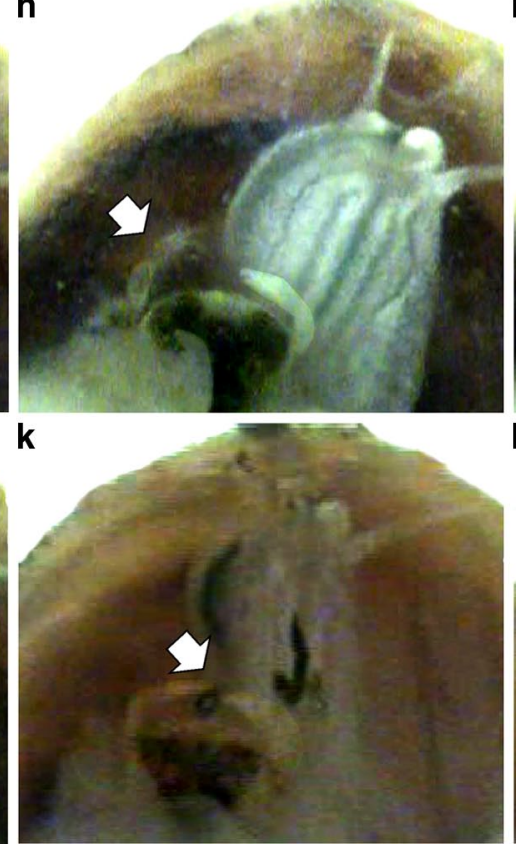

C
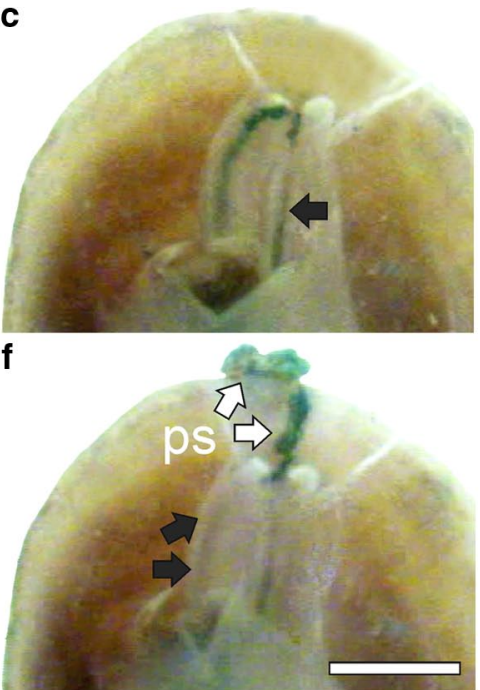

i

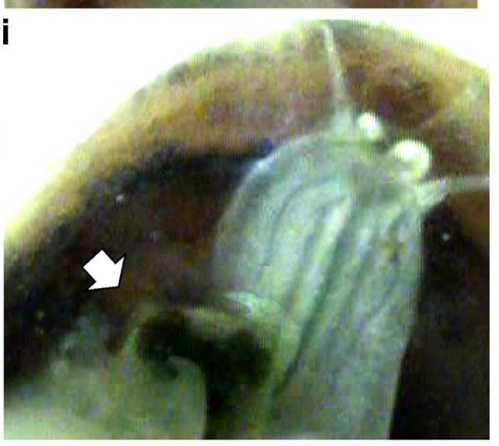

I

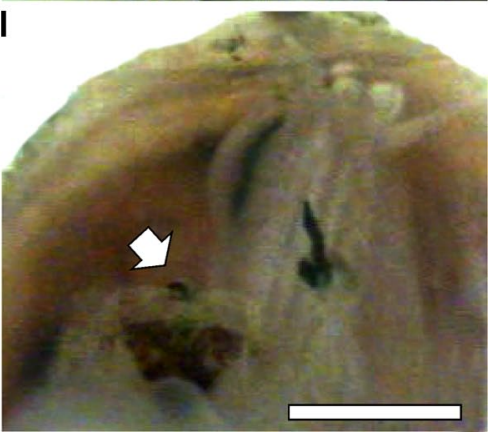

Fig. 3 a-f Feeding behavior of the slipper limpet $C$. cachimilla. Phytoplankton was accumulated in a mucous cord $(\mathrm{mc})$ inside the food canal, and then, it was transported to the mouth (mo). a-d Gradual movement of the mucous cord. Note that the esophagus (es) bears a greenish coloration (black arrow in b-d) corresponding to the phytoplankton mucous ingested. e, f Food canal empty (black arrows) and rejection of pseudofeces (ps) (white arrows). g-l Feeding behav-

the limpet's neck. Crabs were never observed to change their position or to move toward the gill or other host structures.

Effect of pea crabs on the clearance rate of Crepidula cachimilla

Calyptraeotheres garthi stage- $\mathrm{V}$ female crabs did not affect the $\mathrm{CR}$ in $C$. cachimilla. Thirty-one out of 62 ior of the pea crab C. garthi inhabiting C. cachimilla. Arrows indicate movement of the left claw. $g$ Initial position, $\mathbf{h}$ crab moves its left claw forward, $\mathbf{i}$ crab immerses its left claw behind the neck of the limpet and picked up mucous, $\mathbf{j}$ crab carries the captured food to its mouth. $\mathbf{k}, \mathbf{l}$ Crab feeds on a piece of mucous cord gripped with the two claws. Pictures were captured from video. Scale bar $0.5 \mathrm{~cm}$

experimental limpets harbored stage- $V$ female crab $(X \pm \mathrm{SD}=5.39 \pm 1.13 \mathrm{~mm} \mathrm{CW})$ while the remaining 28 experimental limpets did not contain crabs. The average $( \pm S D) C R$ in limpet harboring and not harboring stage- $\mathrm{V}$ female crabs was $0.112 \pm 0.047$ and $0.127 \pm 0.053 \mathrm{~L} \mathrm{~h}^{-1}$ ind $^{-1}$, respectively. No significant differences in $\mathrm{CR}$ were found between limpets harboring or without stage- $\mathrm{V}$ female crabs $\left(t\right.$ test, $t_{57}=0.116$, $P=0.269)$. 

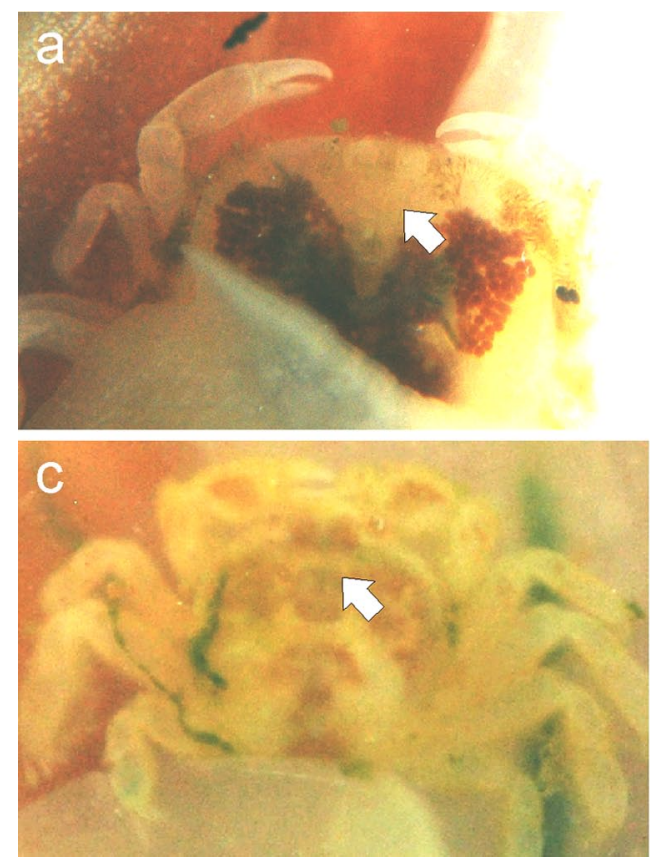

Fig. 4 Dorsal view of the pea crab C. garthi $(\mathbf{a}, \mathbf{b}$ mature female and c, $\mathbf{d}$ male) in the mantle cavity of the slipper limpet $C$. cachimilla. Arrows indicate the stomach of crabs. Left pictures show empty and

Effect of pea crabs on mucous cord formation and pseudofeces elimination in Crepidula cachimilla

Stage-V female crabs did not affect PM and EP in $C$. cachimilla. The average $( \pm \mathrm{SD}) \mathrm{PM}$ in limpet harboring and not harboring stage- $\mathrm{V}$ female crabs was $4.52 \pm 2.65$ and $5.25 \pm 1.59 \mathrm{~h}^{-1}$, respectively. No significant differences in PM were observed between limpets harboring and not harboring stage- $\mathrm{V}$ female crabs $\left(t\right.$ test, $t_{29}=1.534$, $P=0.136)$. The average $( \pm \mathrm{SD}) \mathrm{EP}$ in limpet harboring and not harboring stage- $\mathrm{V}$ female crabs was $0.27 \pm 0.41$ and $0.42 \pm 0.52 \mathrm{~h}^{-1}$, respectively. No significant differences in $\mathrm{EP}$ were observed between limpets harboring and not harboring stage- $\mathrm{V}$ female crabs (Mann-Whitney $U$ test, $\left.U=92.5, N_{1}=17, N_{2}=14, P=0.277\right)$.

Effect of pea crabs on the body condition of Crepidula cachimilla

In the austral spring, female crabs (stages II-V) did not impact the condition of $C$. cachimilla. The average $( \pm \mathrm{SD})$ $\mathrm{CI}$ in limpet harboring and not harboring adult female crabs was $5.41 \pm 3.39$ and $4.86 \pm 2.68$, respectively. No significant differences between these CIs were observed ( $t$ test, $\left.t_{40}=0.944, P=0.351\right)$. The ANCOVA showed no significant effect of $C$. garthi on host body weight (Table 3). The interaction term of the ANCOVA was not significant (Table 3).
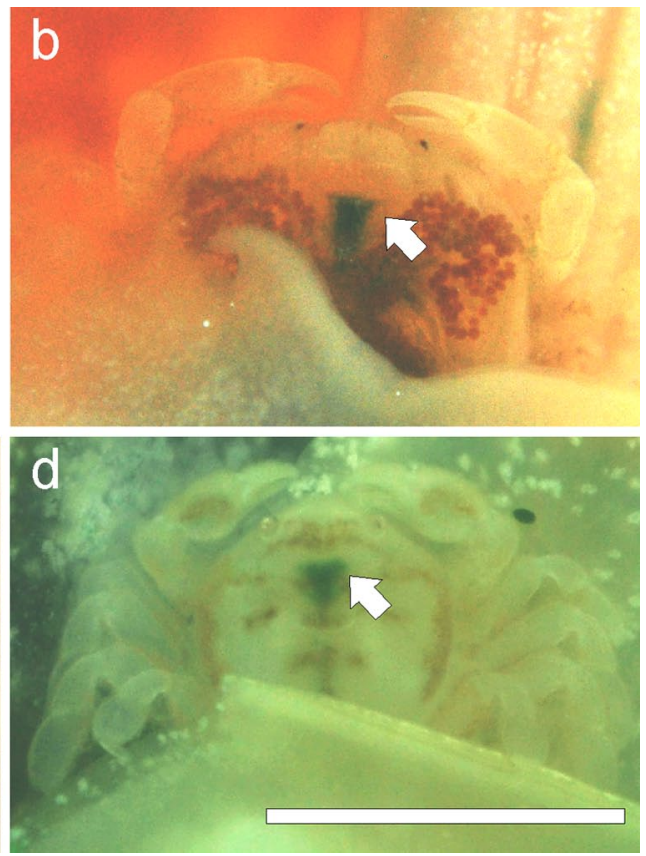

'whitish' crab stomachs before feeding. Right pictures show filled 'greenish' crab stomachs after feeding. Scale bar $0.5 \mathrm{~cm}$

During the austral summer, adult female crabs of $C$. garthi affected the condition of $C$. cachimilla. The average $( \pm \mathrm{SD}) \mathrm{CI}$ in limpets harboring and not harboring adult female crabs was $5.01 \pm 1.16$ and $4.19 \pm 0.71$, respectively. Significant differences were observed when we compared the $\mathrm{CI}$ of limpets harboring and not harboring adult female crabs ( $t$ test, $t_{82}=3.79, P<0.001$ ). The interaction term of the ANCOVA was significant (Table 3). The J-N test detected differences in the elevation of the lines depicting the relationship between body weight and SL only in limpets $\geq 29.6 \mathrm{~mm} \mathrm{SL}$ (Fig. 5). In contrast, the condition of limpets ranging in size between 17.1 and $29.6 \mathrm{~mm}$ SL was not affected by the presence of the female crabs (Table 3 ). Thus, the J-N test shows that the largest but not the smallest limpets in the population improved their condition when hosting $C$. garthi during the austral summer.

Lastly, during the austral winter, adult female crabs of $C$. garthi impacted the condition of $C$. cachimilla. However, by contrast to that observed during the austral summer, the condition of limpets harboring crabs was lower than that of limpets not harboring crabs. The average $( \pm \mathrm{SD}) \mathrm{CI}$ in limpets harboring and not harboring adult female crabs was $5.39 \pm 2.46$ and $6.19 \pm 1.94$, respectively. Significant differences were observed when we compared the CI of limpets harboring and not harboring adult female crabs ( $t$ test, $t_{140}=3.26, P=0.001$ ). The interaction term of the ANCOVA was significant (Table 3 ). The $\mathrm{J}-\mathrm{N}$ test detected significant differences in the elevation of the lines depicting 
Table 3 Result of ANCOVAs of soft body weight against shell length in limpet of $C$. cachimilla harboring and not harboring female crabs (stages II-V) of $C$. garthi during spring, summer and winter

\begin{tabular}{|c|c|c|c|c|c|}
\hline ANCOVA & SS & $d f$ & MS & $F$ & JN \\
\hline \multicolumn{6}{|l|}{ Spring } \\
\hline Slope (interaction term) & 0.061 & 1 & 0.061 & 3.234 n.s. & \\
\hline $\begin{array}{l}\text { Elevation (presence of } \\
\text { female crab term) }\end{array}$ & 0.029 & 1 & 0.029 & 1.469 n.s. & - \\
\hline Residual & 0.712 & 38 & 0.019 & & \\
\hline \multicolumn{6}{|l|}{ Summer } \\
\hline Slope (interaction term) & 0.131 & 1 & 0.131 & $10.62 * *$ & \\
\hline $\begin{array}{l}\text { Elevation (presence of } \\
\text { female crab term) }\end{array}$ & 0.146 & 1 & 0.146 & $11.87 * *$ & $17.1-29.6$ \\
\hline Residual & 0.987 & 80 & 0.012 & & \\
\hline \multicolumn{6}{|l|}{ Winter } \\
\hline Slope (interaction term) & 0.116 & 1 & 0.116 & $7.585^{*}$ & \\
\hline $\begin{array}{l}\text { Elevation (presence of } \\
\text { female crab term) }\end{array}$ & 0.108 & 1 & 0.108 & $7.038^{*}$ & $13.9-31.7$ \\
\hline Residual & 2.114 & 138 & 0.015 & & \\
\hline
\end{tabular}

For comparisons where slopes differ, the Johnson-Neyman (JN) test provides the depth range $(\mathrm{mm})$ in which elevations are not significantly different

Significant $P$ values are marked by one $(<0.05)$ or two $(<0.001)$ asterisks

n.s. not significant

the relationship between body weight and SL only in limpets $\geq 31.7 \mathrm{~mm}$ SL (Fig. 5). By contrast, the body weight of limpets ranging in size between 13.9 and $31.7 \mathrm{~mm} \mathrm{SL}$ was not affected by the presence of female crabs (Table 3). Thus, the J-N test shows that the largest but not the smallest limpets in the population experienced a decrease in their condition when hosting $C$. garthi during the austral winter.

\section{Discussion}

Females from three slipper limpet species halt offspring production (i.e., spawning and brooding) during breeding season when infested by stage II-V females of the pea crab C. garthi. Experiments conducted with one of the limpet hosts, $C$. cachimilla, demonstrated that limpets infested with female pea crabs (stage-V) did not spawn eggs during a 90-day study period while crab-free limpets (8 out of the 15) did spawn and brood embryos repeatedly during the same time period. In turn, limpet of $C$. cachimilla (2 out of $5)$ quickly resumed reproduction soon after pea crabs were removed from the space (i.e., brooding chamber) used by limpets to brood embryos. Our experiments also showed that $C$. garthi is nutritionally dependent on limpets. $C$. cachimilla filters microorganisms from the water column and concentrate captured particles into mucous cords. $C$.

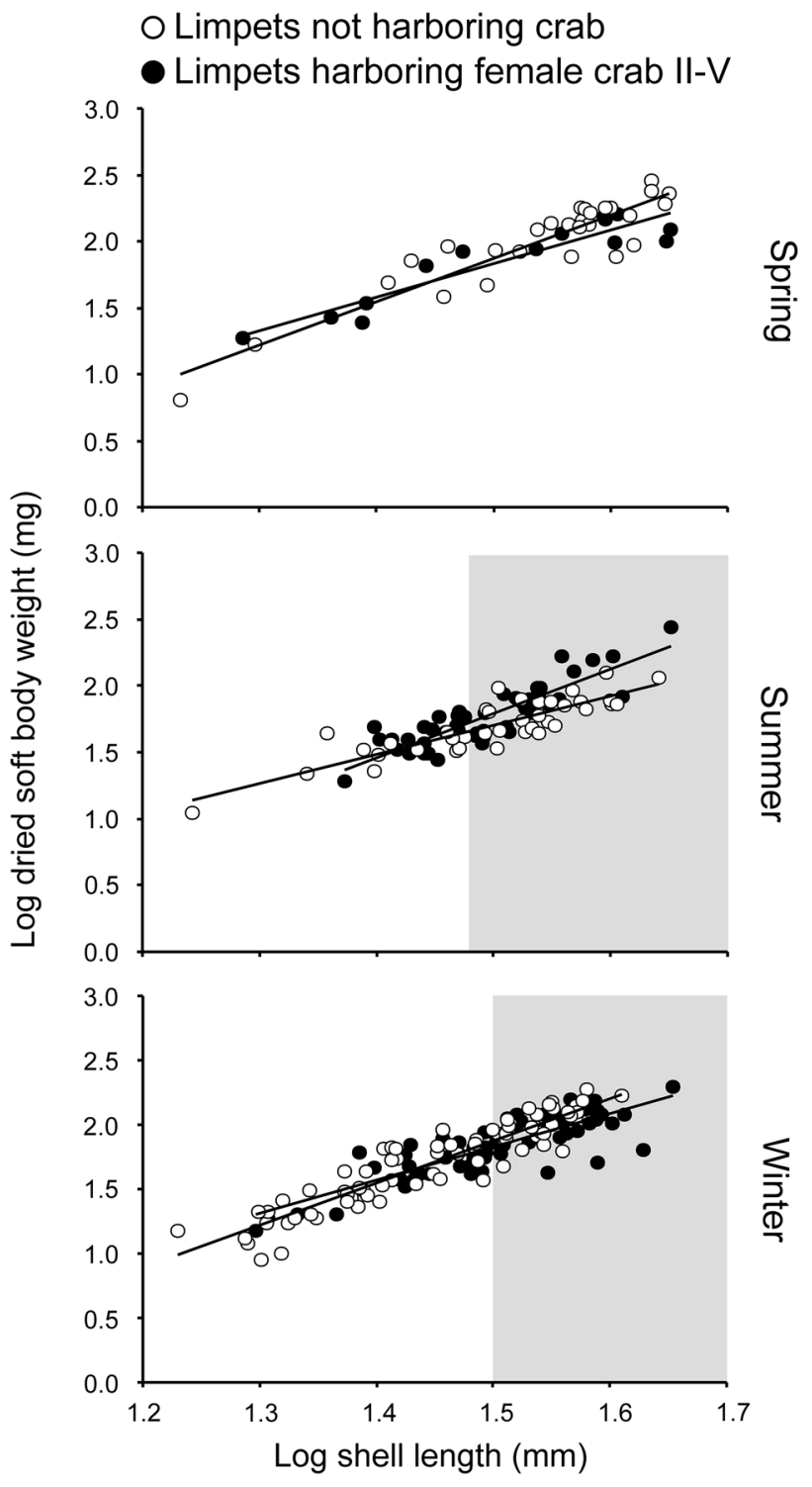

Fig. 5 Relationship between soft body weight and shell length in $C$. cachimilla harboring and not harboring female pea crabs (stages II$\mathrm{V})$. The size range in which there was a significant effect of the crab on the host condition is highlighted in gray

garthi 'steals' portions of phytoplankton-rich mucous cords while limpets are transporting them from the neck to the mouth. Finally, depending upon season, adult female crabs impact (=reduce), improve (=increase) or do not alter the condition of infested limpets of $C$. cachimilla. Overall, our data corroborate that stage II-V female of $C$. garthi should be considered parasites of $C$. cachimilla, $C$. argentina and B. odites as previously suggested (Ocampo et al. 2014). Furthermore, our data suggest pea crabs do castrate, at least temporarily, infested female limpet hosts.

Some life history traits, common to macro-parasitic castrators, are also observed in the studied pea crab, which 
provides additional support for the idea that $C$. garthi is a parasitic castrator. Our results show that castration in the studied limpets is 'intensity-independent,' i.e., a single individual female crab completely hampers reproduction of its limpet host, as occurs in many other parasitic castrators (Kuris 1974; Lafferty and Kuris 2009). Also, C. garthi attains a large body size with respect to that of limpets (see Fig. 2), exhibits a solitary life-style, and grows concomitantly with their host individuals (Ocampo et al. 2012a), as noted before for many other macro-parasitic castrators (Kuris and Lafferty 2000). Altogether, the information above represents strong evidence that the pea crab $C$. garthi, and probably other species from the same genus, acts as parasitic castrator of slipper limpets.

Two hypotheses might explain the observed reproductive cessation in infested limpets. First, the 'energy drain' hypothesis proposes that parasitic castrators, such as $C$. garthi, cause reproductive cessation by depleting energy reserves from host individuals due to food diversion and/ or damage of tissues imposed by these parasites (Walker 1977; Van Wyk 1982; Polak 1996). Alternatively, reproductive cessation of infested limpets might be simply due to the physical presence of crabs within hosts that interferes with (inhibits) reproduction, as reported in the pea crab Calyptraeotheres sp. and the slipper limpet Crepipatella fecunda from the southeastern Pacific (Chaparro et al. 2001).

Our experiments showed that there were no differences in the feeding behavior of limpets harboring and not harboring mature female pea crabs. For a given effort of filtration, $\mathrm{CR}$, the production of mucous cords and the rate of pseudofeces elimination did not vary between infested and crab-free limpets. At first glance, these results provide partial support for the energy drain hypothesis. Pea crabs of $C$. garthi acquire food directly from hosts, and infested limpets do not modify their feeding activity to counteract this nutrient loss. Thus, infested limpets are expected to ingest less food over long periods of time, and subsequent food deprivation is expected to cause host individuals to halt reproduction (Van Wyk 1982; Polak 1996). However, our field measurements also demonstrated that during the reproductive season (i.e., austral summer and spring), the body condition of infested limpets of $C$. cachimilla either increased or was not affected by pea crabs. Castration caused by parasite-mediated energy draining is commonly accompanied by a decrease in the overall condition and/or growth rate of host individuals, as reported before for various castrated hosts (Anderson 1977; Sousa 1983; Polak 1996), including bivalves infested by pea crabs (e.g., the blue mussel Mytilus galloprovincialis inhabited by the crab Pinnotheres pholadis-Yoo and Kajihara 1985; the oyster Crassostrea virginica infested by the pea crab Zaops ostreus-O'Beirn and Walker 1999). Thus, our results contrast with our expectations (i.e., reduced body condition of infested limpets) if the nutritional drain hypothesis was explaining reproductive cessation in the studied limpets.

A second line of reasoning indicating that $C$. garthi does not castrate limpets by depleting their energy reserves is the prompt recovery of reproductive activity in host individuals experimentally stripped of crabs. Castration generally persists for the lifetime of infested host individuals, although reproduction in hosts might, sometimes, resume after the castrator's death (Kuris et al. 1980; Lafferty and Kuris 2009). If castration in limpets results from pea crabs depleting energy, these limpets are expected to take a considerable amount of time to accumulate energetic reserves de novo and divert them to oogenesis. Nevertheless, in our experiments, soon after experimental extraction of pea crabs (7-10 days), formerly infested limpets quickly resumed reproduction. Furthermore, although we did not quantify the number of oocytes in infested and non-infested limpets, macroscopic observations revealed that the ovaries in infested limpets of $C$. cachimilla were full of mature oocytes. The above implies that infected limpets were reproductively active and ready to spawn. Thus, our data argue against the notion that crabs cause energetic stress to limpets during the reproductive season. On the contrary, that slipper limpets are capable of quickly recovering reproductive activity once pea crabs are extracted argue in favor of the 'steric interference' mechanism explaining host castration in the studied species. If pea crabs inhibit reproduction by merely filling the limpets' brooding space (Chaparro et al. 2001), it is expected that once the occupied space is (experimentally) emptied, the limpet would spawn again. A previous study has also demonstrated that the limpet $C$. fecunda promptly resumes reproduction after Calyptraeotheres sp. crabs are extracted (Chaparro et al. 2001).

The 'steric interference' hypothesis also explains why the smallest pea crabs that partially fill the brooding chamber do not halt reproduction in limpets (Chaparro et al. 2001). In the field, $C$. cachimilla and $C$. argentina brooded egg masses and harbored small juveniles (pre-hard) or hard stages of $C$. garthi at the same time. Interestingly though, pea crabs from all sizes (i.e., the small pre-hard and hard stages, and also the comparatively large stage II$\mathrm{V}$ females) halted reproduction in $B$. odites. Importantly, $B$. odites attains smaller mean and maximum body sizes than those attained by the other studied limpet species (Cledón and Penchaszadeh 2001; Ocampo et al. 2012a). Thus, the comparatively small brooding chamber of the small $B$. odites is expected to become completely filled by small crabs, including pre-hard and hard stages. Overall, as previously demonstrated in the slipper limpet $C$. fecunda (Chaparro et al. 2001), space availability within the incubatory chamber seems to be one of the key factors determining spawning and brooding in the studied limpet species. 
Interestingly, we observed that the body condition of limpets infested by stage II-V female crabs decreased, increased or was not affected during winter, summer and spring, respectively. The reduction in the body condition of infested limpets during winter might result from the competition for food between limpet and crab, as reported before in other host/pea crab systems (Stauber 1945; Bierbaum and Shumway 1988; De Bruyn et al. 2009). However, the actual reasons for these seasonal changes are presently unknown. A possible explanation for the increase in CI observed during summer might have to do with castration-mediated shifts in the amount of energy that infested limpets partition between somatic growth and reproduction. During summer, crab-free limpets of $C$. cachimilla allocate resources to embryo production, spawning and brooding (Cledón et al. 2004). However, infested limpets do not reproduce due to the presence of pea crabs that impede the spawning and/or brooding process. Thus, during the summer, limpets appear to have a surplus of energy and reallocation of this energy to growth might explain the increase in body condition. Additional studies examining the energetic content of gonads and somatic tissues of infested and crab-free limpets are needed to determine whether $C$. garthi do alter the energy budget of limpets as we have hypothesized above. As for now, we interpreted the increased condition in summer as a consequence of pea crabs halting host reproduction.

Finally, given that $C$. garthi inhabits the same space that the hosts use to spawn and incubate egg masses, an alternative explanation for host castration in the studied limpets is that the crabs directly prey upon the limpet's embryos once they colonize the host's brooding chamber. However, our laboratory experiments showed that the feeding behavior of C. garthi is highly specialized; crabs feed only by stealing pieces of phytoplankton-rich mucous. Importantly, crabs were never observed to prey upon the limpet's eggs. We found no evidence of predation (i.e., rest of eggs or capsules) in any of the 357 limpets (242 C. cachimilla, 56 B. odites, 59 C. argentina) that hosted $C$. garthi in the field. Additionally, the egg masses of the 8 brooding limpets ( 3 C. cachimilla and 5 C. argentina) that harbored crabs when collected have no signs (i.e., broken capsules) of predation. Lastly, that a 'false' pea crab produced the same result than an actual pea crab in a closely related host-parasitic castrator system (see Chaparro et al. 2001) also argues against the idea that castration might be caused by pea crabs feeding on eggs.

\section{Conclusions}

Overall, the pea crab C. garthi does not castrate limpets by draining energetic resources from host individuals.
Instead, our field observations and laboratory experiments suggest that host castration results from pea crabs occupying the limpet's incubatory space. The 'steric interference' hypothesis also appears to explain seasonal changes in the limpet's body condition. During the reproductive season (i.e., austral spring and summer), pea crabs do not impact the condition of limpet hosts. We suggest that during this season, castrated limpets devote surplus energy (not used for reproduction due to the presence of the pea crab) into somatic growth, as reported to occur in other castrated hosts (Ebert et al. 2004; Hall et al. 2007). In turn, during winter, the limpet's condition is adversely affected by the feeding habit of pea crabs. We argue in favor of additional experimental and natural history studies to keep improving our understanding of the remarkable symbiotic interaction established by pea crabs and a diverse array of hosts in the marine environment.

Acknowledgments We are grateful to Emiliano Pisani for providing us with phytoplankton, Nicolas Chiaradia for helping us with photographs, and the fishermen Mario (el Ruso) and Gabriel for helping us in collecting limpets at Piedras Coloradas. We also thank Enrique Morsan and colleagues at IBMP (Instituto de Biología Marina y Pesquera, Almirante Storni) for their hospitality during sampling at San Matias Gulf. Part of the material used for the present study was collected by E.O. during the campaign Mejillón II-2009, on board the Oceanographic R/V Puerto Deseado. We are grateful to two anonymous reviewers for valuable suggestions on the manuscript. The present work was partially supported by PIP 2008 112-384 200-80102190 (CONICET-Consejo Nacional de Investigaciones Científicas y Técnicas de Argentina) and EXA 515/10 (UNMdP-Universidad Nacional de Mar del Plata, Argentina). E.O. received scholarship support from CONICET. The present results are part of the PhD dissertation of E.O. This is a contribution of the Smithsonian Marine Station at Fort Pierce, Smithsonian Institution.

\section{References}

Anderson G (1977) The effects of parasitism on energy flow through laboratory shrimp populations. Mar Biol 42:239-251

Becker C, Brandis D, Storch V (2011) Morphology of the female reproductive system of European pea crabs (Crustacea: Brachyura: Pinnotheridae). J Morphol 272:12-26

Berner L (1952) Biologie de Pinnotheres pisum Penn. (Decapode Brachyoure). Extr Bull Soc Zool Fr 77:344-349

Bierbaum RM, Shumway SE (1988) Filtration and oxygen consumption in mussels, Mytilus edulis, with and without pea crab, Pinnotheres maculatus. Estuaries 11:264-271

Blower SM, Roughgarden J (1987) Population dynamics and parasite castration: a mathematical model. Am Nat 129:730-754

Chaparro OR, Saldivia CL, Paschke KA (2001) Regulatory aspects of the brood capacity of Crepidula fecunda, Gallardo 1979 (Gastropoda: Calyptraeidae). J Exp Mar Biol Ecol 266:97-108

Chaparro OR, Thompson RJ, Pereda SV (2002) Feeding mechanisms in the gastropod Crepidula fecunda. Mar Ecol Prog Ser 234:171-181

Cledón M, Penchaszadeh P (2001) Reproduction and brooding of Crepidula argentina (Simone, Pastorino, Penchaszadeh, 2000). Nautilus 115:15-21 
Cledón M, Simone LR, Penchaszadeh PE (2004) Crepidula cachimilla (Mollusca: Gastropoda): a new species from Patagonia, Argentina. Malacologia 46:185-202

Coughlan J (1969) The estimation of filtering rate from the clearance of suspensions. Mar Biol 2:356-358

De Bruyn C, Rigaud T, David B, De Ridder C (2009) Symbiosis between the pea crab Dissodactylus primitivus and its echinoid host Meoma ventricosa: potential consequences for the crab mating system. Mar Ecol Prog Ser 375:173-183

Ebert D, Carius HJ, Little T, Decaestecker E (2004) The evolution of virulence when parasites cause host castration and gigantism. Am Nat 164:S19-S32

Hall SR, Becker C, Cáceres CE (2007) Parasitic castration: a perspective from a model of dynamic energy budgets. Integr Comp Biol 47:295-309

Høeg JT (1995) The biology and life cycle of the Rhizocephala (Cirripedia). J Mar Biol Assoc UK 75:517-550

Huitema BE (1980) The analysis of covariance and alternatives: statistical methods for experiments, quasi-experiments, and singlecase studies. Wiley, New York

Hunka S, Leighton J (1997) Defining Johnson-Neyman regions of significance in the three-covariate ANCOVA using mathematica. J Educ Behav Stat 22:361-387

Hurd H (1993) Reproductive disturbances induced by parasites and pathogens of insects. In: Beckage NE, Thompson SA, Federici BA (eds) Parasites and pathogens of insects. Academic Press, San Diego, pp 87-105

Kuris AM (1974) Trophic interactions: similarity of parasitic castrators to parasitoids. Q Rev Biol 49:129-148

Kuris AM, Lafferty KD (2000) Parasite-host modelling meets reality: adaptive peaks and their ecological attributes. In: Poulin R, Morand S, Skorping A (eds) Evolutionary biology of host-parasite relationships: theory meets reality. Elsevier Science BV, Amsterdam, pp 9-26

Kuris AM, Poinar GO, Hess RT (1980) Post-larval mortality of the endoparasitic isopod castrator Portunion conformis (Epicaridea: Entoniscidae) in the shore crab, Hemigrapsus oregonensis, with a description of the host response. Parasitology 80:211-232

Lafferty KD, Kuris AM (2009) Parasitic castration: the evolution and ecology of body snatchers. Trends Parasitol 25:564-572

Loker ES, Adema CM (1995) Schistosomes, echinostomes and snails: comparative immunobiology. Parasitol Today 11:120-124

Margulis L, Fester R (1991) Symbiosis as a source of evolutionary innovation. MIT Press, Cambridge

Marin V, Huntley ME, Frost B (1986) Measuring feeding rates of pelagic herbivores, analysis of experimental design and methods. Mar Biol 93:49-58

McLaughlin PA (1980) Comparative morphology of recent Crustacea. W.H. Freeman, San Francisco

Miura O, Kuris AM, Torchin ME, Hechinger RF, Chiba S (2006) Parasites alter host phenotype and may create a new ecological niche for snail hosts. Proc R Soc Lond B Biol 273:1323-1328

Møller Christensen A, McDermott JJ (1958) Life-history and biology of the oyster crab, Pinnotheres ostreum Say. Biol Bull 114:146-179

O'Beirn FX, Walker RL (1999) Pea crab, Pinnotheres ostreum Say, 1817, in the eastern oyster, Crassostrea virginica (Gmelin, 1791): prevalence and apparent adverse effects on oyster gonad development. Veliger 42:17-20

Ocampo EH, Nuñez JD, Cledón M, Baeza JA (2012a) Host-specific reproductive benefits, host selection behavior and host use pattern of the pinnotherid crab Calyptraeotheres garthi. J Exp Mar Biol Ecol 429:36-46

Ocampo EH, Nuñez JD, Cledón M, Robles R (2012b) New record of calyptraeid hosts for the pea crab Calyptraeotheres garthi (Fenucci, 1975) (Decapoda, Pinnotheridae) in Argentina. Crustaceana 85:1463-1474

Ocampo EH, Menone ML, Iturburu FG, Nuñez JD, Baeza JA (2014) Effect of the endosymbiotic pea crab Calyptraeotheres garthi on the metabolic rate and oxidative status of the slipper limpet Crepidula cachimilla. Invertebr Biol 133:170-179

Orton JH (1920) Mode of feeding and sex-phenomena in the pea-crab (Pinnotheres pisum). Nature 106:533-534

Pearce JB (1966) The biology of the mussel crab, Fubia subquadrata from the water of the San Juan Archipelago, Washington. Pac Sci 20:3-35

Pechenik JA, Eyster LS (1989) Influence of delayed metamorphosis on the growth and metabolism of young Crepidula fornicata (Gastropoda) juveniles. Biol Bull 176:14-24

Polak M (1996) Ectoparasitic effects on host survival and reproduction: the Drosophila-Macocheles association. Ecology 77:1379-1389

Schmitt WL, McCain JC, Davidson ES (1973) Decapoda I, Brachyura I, family Pinnotheridae. In: Gruner HE, Holthuis LB (eds) Crustaceorum catalogus. Dr. W. Junk BV, Den Haag, pp 1-160

Shumway SE, Ward JE, Heupel E, Holohan BA, Heupel J, Heupel T, Padilla DK (2014) Observations of feeding in the common Atlantic slippersnail Crepidula fornicata $\mathrm{L}$., with special reference to the "mucus net". J Shellfish Res 33:279-291

Sokal RR, Rohlf FJ (1981) Biometry. Freeman, San Francisco

Sorensen RE, Minchella DJ (2001) Snail-trematode life history interactions: past trends and future directions. Parasitology 123:S3-S18

Sousa WP (1983) Host life-history and the effect of parasitic castration on growth: a field - study of Cerithidea californica Haldeman (Gastropoda, Prosobranchia) and its trematode parasites. J Exp Mar Biol Ecol 73:273-296

Stauber LA (1945) Pinnotheres ostreum, parasitic in the American oyster, Ostrea (Gryphaea) virginica. Biol Bull 88:269-291

Thain JE (1984) Effects of mercury on the prosobranch mollusc Crepidula fornicata: acute lethal toxicity and effects on growth and reproduction of chronic exposure. Mar Environ Res 12:285-309

Van Wyk PM (1982) Inhibition of the growth and reproduction of the porcellanid crab Pachycheles rudis by the bopyrid isopod, Aporobopyrus muguensis. Parasitology 85:459-473

Walker SP (1977) Probopyrus pandalicola: discontinuous ingestion of shrimp haemolymph. Exp Parasitol 41:198-205

Williams JD, Boyko CB (2012) The global diversity of parasitic isopods associated with crustacean hosts (Isopoda: Bopyroidea and Cryptoniscoidea). PLoS One 7:e35350

Yoo M, Kajihara T (1985) The effect of the pea crab Pinnotheres pholadis on the reproductive capacity of the blue mussel Mytilus edulis galloprovincialis. Bull Korean Fish Soc 18:581-585

Zar JH (1999) Biostatistical analysis. Prentice-Hall, Englewood Cliffs 